\title{
Leaf gas exchange, phosphorus uptake, growth and yield responses of cotton cultivars to different phosphorus rates
}

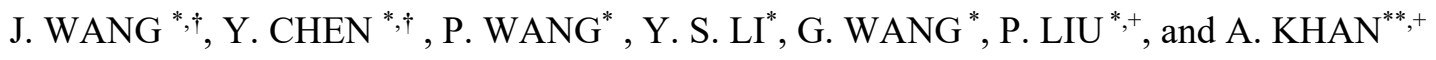 \\ Xinjiang Agricultural Reclamation Academy of Sciences, Shihezi, 832003, Xinjiang, China* \\ Key Laboratory of Plant Genetic and Breeding, College of Agriculture, Guangxi University, Nanning, 53005, China**
}

\begin{abstract}
Growth and physiological responses of cotton (Gossypium hirsutum L.) cultivars with different phosphorus (P) efficiencies under variable $\mathrm{P}$ environment are poorly known. Therefore, this study explored effects of normal $\mathrm{P}\left[\mathrm{P}^{+}, 70 \mathrm{~kg}\left(\mathrm{P}_{2} \mathrm{O}_{5}\right) \mathrm{ha}^{-1}\right]$ and without $\mathrm{P}\left(\mathrm{P}^{-}, 0 \mathrm{~kg} \mathrm{ha}^{-1}\right)$ on yield, growth, and physiology of different P-efficient cultivars [low-efficient Xinluzao $13\left(\mathrm{~L}_{1}\right)$ and Xinluzao $26\left(\mathrm{~L}_{2}\right)$; medium-efficient Xinluzao $10\left(\mathrm{M}_{1}\right)$ and Xinluzao $24\left(\mathrm{M}_{2}\right)$; high-efficient Zhongmiansuo 42 $\left(\mathrm{H}_{1}\right)$ and Xinluzao19 $\left.\left(\mathrm{H}_{2}\right)\right]$. Cotton growth and yield was higher in $\mathrm{H}_{1}$ and $\mathrm{H}_{2}$ cultivars under $\mathrm{P}^{+}$compare to $\mathrm{P}^{-}$. Leaf photosynthesis, intercellular $\mathrm{CO}_{2}$ concentration, stomatal conductance, and net assimilation rate increased under $\mathrm{P}^{+}$and in high-efficient cultivars. Greater Rubisco activity and higher soluble sugar content further promoted P uptake and utilization efficiency which resulted in a higher yield under normal $\mathrm{P}^{+}$than that at $\mathrm{P}^{-}$treatment. High-P-efficient cultivars have the potential to increase the yield by improving cotton growth and physiological attributes under $\mathrm{P}^{+}$.
\end{abstract}

Additional key words: enzymatic activity; leaf area index; net assimilation rate; photosynthesis; photosynthetic pigments.

\section{Introduction}

Cotton production has increased due to the introduction of high-yielding varieties. However, fertility of cotton raising soils has decreased, because of continuous cultivation of arable crops, and inadequate supply of organic and inorganic fertilizers (Jayakumar and Surendran 2017). Nevertheless, to pursuit higher yields in order to meet the demand of fibre and food for the expanding global population with poor management practices, i.e., mismanagement of inputs and imbalanced fertilizers application, has led to depleted soil nutrients and raised concerns about the potential long-term adverse impacts on soil fertility, productivity, and environmental quality (Surendran and Murugappan 2010). Poor and marginal farmers often use suboptimal rates of $P$ fertilizers and choose wrong cultivars due to lack of resources available to them. In future, higher input costs and limited nutrient resources can further worsen this situation resulting in rising fertilizer prices and increases of production costs
(Jayakumar and Surendran 2017). Under such circumstances, it is important to understand the responses of cotton cultivars under various $\mathrm{P}$ supply.

Phosphorus is an essential mineral nutrient for normal growth and development of cotton crops and its deficiency or suboptimal supply result in lower photosynthesis and metabolism leading to a substantial yield reduction (Jayakumar and Surendran 2017, MacDonald et al. 2011). However, under limited soil $\mathrm{P}$ availability, plants often experience morphological and physiological changes, i.e., stunted growth, reduction in a leaf number, leaf area, reduced photosynthesis, increased leaf chlorophyll (Chl) and protein contents (Lauer et al. 1989, Rao and Terry 1989, Suriyagoda et al. 2014). Depending on root penetration and proliferation, availability of $\mathrm{P}$ in the rhizosphere may vary which affects $\mathrm{P}$ uptake in cotton plants (Jayakumar and Surendran 2017). Root growth is not restricted under $\mathrm{P}$ deficiency as much as the shoot

Received 26 October 2017, accepted 9 March 2018, published as online-first 27 June 2018.

+Corresponding author; e-mail liu19901070@126.com; azizkhanturlandi@gmail.com

Abbreviations: $C_{\mathrm{i}}$ - intercellular $\mathrm{CO}_{2}$ concentration; $\mathrm{Chl}$ - chlorophyll; CGR - crop growth rate; DM - dry mass; FM - fresh mass; $g_{\mathrm{m}}$ - mesophyll conductance; $g_{\mathrm{s}}$ - stomatal conductance; HP - high P efficiency; LAI - leaf area index; LP - low P efficiency; MP medium P efficiency; NAR - net assimilation rate; $P_{\mathrm{N}}$ - net photosynthetic rate; $\mathrm{PP}$ - photosynthetic potential.

Acknowledgements: This study was financially supported by the National Natural Science Foundation of China (Grant No. 31660365), the National Key Research and Development Program of China (2016YFD0200405) and the Program of Youth Science and Technology Innovation Leader of The Xinjiang Production and Construction Corps.

$\dagger$ These authors contributed equally to this work. 
growth. More carbohydrates are distributed to the roots to assist in root exploration of the soil and expansion to acquire more $\mathrm{P}$ (Girma et al. 2007).

Current agriculture management practices commonly experience low plant nutrient-use efficiency due to natural chemical sorption and transformations. For example, up to $90 \%$ of $\mathrm{P}$ fertilizer applied to soil is unavailable to plants because it binds to $\mathrm{Ca}, \mathrm{Al}$, and Fe-bearing soil mineral surfaces or is lost from the ecosystem through leaching (Randriamanantsoa et al. 2013). Low availability of soil $\mathrm{P}$ significantly influences root morphological and biochemical processes arresting plant growth and development in cotton. This phenomenon also induces formation and secretion of acid phosphorylase and other special enzymes of the root system and upregulation of the gene expression of high-affinity P translocator (Yan et al. 1997, 2000; Lefebvre et al. 1990, Muchhal and Raghothama 1999). However, optimal $\mathrm{P}$ has the potential to enhance plant adaptation to stressful conditions resulting in a higher nutrient uptake; and utilization ultimately increases cotton yields. In contrast, low $\mathrm{P}$ hampers plant growth which in turn causes substantial yield loss. Different plant genotypes display genetic diversity in the absorption and utilization ratios of $\mathrm{P}$. Cotton cultivars with high $\mathrm{P}$ efficiency may increase plant performance under low $\mathrm{P}$ conditions by increasing root activity, water, and $\mathrm{P}$

\section{Materials and methods}

Experimental site: An experiment was carried out at the experimental farm of Xinjiang Agricultural Reclamation Academy of Sciences, in the northwestern China $\left(45^{\circ} 19^{\prime} \mathrm{N}\right.$, $74^{\circ} 56^{\prime} \mathrm{E}$ ) during 2014 and 2015 growing season. A composite soil sample was obtained using a soil augur from the experimental area prior to planting of cotton plants. The soil characteristics comprised of $1.14 \%$ organic matter, $32.1 \mathrm{mg}$ (alkali-hydrolyzed nitrogen) $\mathrm{kg}^{-1}$, $8.5 \mathrm{mg}$ (available phosphorus, $\left.\mathrm{P}_{2} \mathrm{O}_{5}\right) \mathrm{kg}^{-1}$, and $128.1 \mathrm{mg}$ (available potassium, $\mathrm{K}_{2} \mathrm{O}$ ) $\mathrm{kg}^{-1}$.

Experimental design: The experiment was designed in a split plot arrangement with six cotton cultivars of different $\mathrm{P}$ efficiencies (Wang et al. 2008), e.g., Xinluzao $13\left(\mathrm{~L}_{1}\right)$, Xinluzao $26\left(\mathrm{~L}_{2}\right)$ with low P efficiency (LP); Xinluzao 10 $\left(\mathrm{M}_{1}\right)$, Xinluzao $24\left(\mathrm{M}_{2}\right)$ with medium P efficiency (MP); Zhongmiansuo $42\left(\mathrm{H}_{1}\right)$, Xinluzao19 $\left(\mathrm{H}_{2}\right)$ with high $\mathrm{P}$ efficiency (HP) under normal phosphorus $\left[\mathrm{P}^{+}, 70 \mathrm{~kg}\left(\mathrm{P}_{2} \mathrm{O}_{5}\right)\right.$ $\mathrm{ha}^{-1}$ and no $\left(\mathrm{P}^{-}, 0 \mathrm{~kg} \mathrm{ha}^{-1}\right)$. A split-plot design with four replicates was used to increase the accuracy of comparisons. The experimental plot size was $30 \mathrm{~m}^{2}(6 \times 5 \mathrm{~m})$. Prior to sowing, the field was leveled followed by cultivation and planking operations. Seeds of different cotton cultivars were sown on raised bed in respective plots. Seedlings were thinned two weeks after emergence to the desired plant population density. Fertilizer nitrogen at the rate of $150 \mathrm{~kg}$ (urea) ha ${ }^{-1}$ with $46 \% \mathrm{~N}$ was supplemented to each plot. Crop management practices, such as acquisition (Sharpley et al. 2015).

The effects of sufficient and deficient P supply on cotton photosynthetic characteristics (Jensen et al. 2002), soluble protein (Rao and Terry 1989), and Chl content (Rao and Terry 1989, Pan et al. 2003), Rubisco activity (Lauer et al. 1989), and net photosynthetic rate $\left(P_{\mathrm{N}}\right)$ (Jensen et al. 2002, Pan et al. 2003) have been reported; but data regarding cotton cultivars with different $\mathrm{P}$ efficiency under different $P$ rates are lacking. Screening and using P-efficient genotypes and cultivars with efficient uptake and utilization ratios of $\mathrm{P}$ can potentially increase $\mathrm{P}$ utilization in plants (Yan et al.1997, Wang and Li 2000, Luo et al. 2016, Wang et al. 2008). Therefore, screening for suitable characteristics of P-efficient cotton cultivars, especially under different $\mathrm{P}$ rates under arid climatic conditions, are essential for reaching optimal yield and for future breeding program. Therefore, this study aimed: (1) to explore effects of sufficient and deficient $\mathrm{P}$ fertilization on different P-efficient cultivars in their yield, growth, physiological attributes; and (2) to determine physiological mechanisms causing differences in yields and $\mathrm{P}$ utilization efficiencies between low-P-, medium-P-, and high-P-efficiency cultivars. These data can provide a theoretical basis for genetic improvement and breeding for the high-P-efficiency in cotton crops.

irrigation, weeding, hoeing, and pesticide application, were implemented to reduce competition for nutrients, light, water, and spacing for a better crop stand. Mepiquat chloride (Kaifeng Lirui Inc., China) was applied as a growth regulator in order to reduce vegetative growth.

Cotton leaf gas-exchange attributes: Net photosynthetic rate $\left(P_{\mathrm{N}}\right)$, stomatal conductance $\left(g_{\mathrm{s}}\right)$, and intercellular $\mathrm{CO}_{2}$ concentration $\left(C_{\mathrm{i}}\right)$ was measured at different reproductive phases, e.g., squaring, flowering, and boll-setting from top functional leaf on the main stem using LI-6400 (LI-COR Inc., NE, USA). These measurements were performed on sunny days between 10:00 and 12:00 a.m. in each unit under the following conditions: light intensity of 1800 $\mu$ mol(photon) $\mathrm{m}^{-2} \mathrm{~s}^{-1}$, the ambient $\mathrm{CO}_{2}$ concentration was $366 \mu \mathrm{mol} \mathrm{mol}{ }^{-1}$, and the vapor pressure was $3.5 \mathrm{kPa}$ at field temperature. Mesophyll conductance $\left(g_{\mathrm{m}}\right)$ was assessed according to Xiao et al. (1998).

Cotton growth, yield, phosphorus uptake and utilization: Ten successive and uniform plants were tagged after emergence to determine plant growth parameters. Cotton plants were carefully uprooted at different growth stages and separated into vegetative and reproductive structures. Leaf area was determined by measuring subsamples with a $\mathrm{Li}$-Cor planimeter (Model $\mathrm{Li}$-3100, $\mathrm{Li}$-COR Inc., Lincoln, USA). Seed cotton yield (g per plant) was calculated by hand-picking all open bolls from each 
subplot. The plants were dried in an electric fan-assisted oven at $105^{\circ} \mathrm{C}$ for $30 \mathrm{~min}$ to stop consumption by respiration and then dried at $80^{\circ} \mathrm{C}$ for $48 \mathrm{~h}$ until a constant mass was obtained. Leaf area index (LAI), crop growth rate, and net assimilation were assessed using the following formula:

$$
\begin{aligned}
& \text { Leaf area index }=\frac{\text { Leaf area per plant }}{\text { Land area occupied by the plant }(\mathrm{cm})} \\
& \text { Crop growth rate }(\mathrm{CGR})=\frac{\mathrm{W}_{2}-\mathrm{W}_{1}}{\mathrm{~A}\left(\mathrm{t}_{2}-\mathrm{t}_{1}\right)} \\
& \text { Net assimilation rate }(\mathrm{NAR})= \\
& =\frac{\left(\mathrm{W}_{2}-\mathrm{W}_{1}\right)\left(\mathrm{LnS}_{2}-\mathrm{LnS}_{1}\right)}{\left(\mathrm{S}_{2}-\mathrm{S}_{1}\right)\left(\mathrm{t}_{2}-\mathrm{t}_{1}\right)}
\end{aligned}
$$

where $\mathrm{W}_{1}$ and $\mathrm{W}_{2}$ are crop dry mass $\left(\mathrm{DM}, \mathrm{g} \mathrm{m}^{-2}\right)$ at initial $\left(\mathrm{t}_{1}\right)$ and final times $\left(\mathrm{t}_{2}\right)$, respectively. Photosynthetic potential (PP) was determined as a product of the leaf area during different growth period and the duration of the growth period. Oven-dried plant organs were analyzed for $\mathrm{P}$ uptake and utilization. The samples were digested according micro-Kjeldahl method (Bremer and Mulvaney 1982). Concentrations of $P$ were expressed on a DM basis and $\mathrm{P}$ uptake was determined as the product of concentration and DM. Cotton plant P efficiency was assessed by obtaining the ratio of DM to single-plant $\mathrm{P}$ uptake.

Chl, soluble protein and Rubisco, $\mathrm{Ca}^{2+}$-ATPase and $\mathbf{M g}^{2+}$-ATPase activities: Chl contents were determined according to the method of He et al. (2002). Briefly, 0.25 $\mathrm{g}$ of fresh leaves was placed in a $100-\mathrm{ml}$ test tube. Plant tissues were homogenized with a polytron homogenizer after addition of 10-15 $\mathrm{ml}$ of pure methanol. The homogenate was then filtered and made up to $100 \mathrm{ml}$ with pure methanol. The $\mathrm{Chl}$ concentration was calculated using spectrophotometer (UV-2401, Shimadzu Corporation, Japan) determined at 652 and $665 \mathrm{~nm}$. Leaf samples $(0.5 \mathrm{~g})$ were homogenized at $4^{\circ} \mathrm{C}$ in $5 \mathrm{ml}$ of cold water and centrifuged at $800 \times g$ for $5 \mathrm{~min}$. The supernatant was stored on ice and the pellet was re-suspended in $3 \mathrm{ml}$ of

\section{Results}

Leaf gas-exchange parameters and $\mathrm{Chl}$ content: Cotton leaf gas-exchange attributes and Chl content of different cultivars was significantly influenced by sufficient $\left(\mathrm{P}^{+}\right)$ and no $\left(\mathrm{P}^{-}\right) \mathrm{P}$ conditions at different growth stages (Table 1). Leaf Chl contents were at peak for HP cultivars compared with MP and LP cultivars at the squaring, flowering, and boll-setting stage under both conditions. However, the contents were significantly higher under $\mathrm{P}^{+}$ compared to $\mathrm{P}^{-}$conditions.

Cotton plant $g_{\mathrm{s}}, g_{\mathrm{m}}$, and $P_{\mathrm{N}}$ increased with the plant development. Compared to LP and MP cultivars, the $g_{\mathrm{s}}$, $g_{\mathrm{m}}$, and $P_{\mathrm{N}}$ increased for HP cultivars at the squaring and flowering stage, although $g_{\mathrm{s}}, g_{\mathrm{m}}$, and $P_{\mathrm{N}}$ decreased at the cold water prior to re-centrifugation $(800 \times g)$ for another $5 \mathrm{~min}$. The supernatants were pooled centrifuged and stored on ice. The pellet was re-suspended in $2 \mathrm{ml}$ of cold water and centrifuged at $800 \times g$ and the supernatant was pooled for analysis of soluble protein content by the Coomassie Blue dye-binding assay of Bradford (1976). The absorbance readings were converted using BSA as standard curve.

The Rubisco activity was assessed according to Dong et al. (1996). The reaction solution composed of 1 mol(Tris-HCl) $\mathrm{L}^{-1}$ (pH 8.0), 1 mmol(EDTA) L $\mathrm{L}^{-1}, 100$ $\operatorname{mmol}\left(\mathrm{MgCl}_{2}\right) \mathrm{L}^{-1}, 50 \mathrm{mmol}(\mathrm{ATP}) \mathrm{L}^{-1}, 2 \mathrm{mmol}\left(\mathrm{NaHCO}_{3}\right)$ $\mathrm{L}^{-1}$, mmol L ${ }^{-1} \mathrm{RuBP}$ (ribulose-1,5-bisphosphate), 15 units of phosphoglyceric acid kinase, 15 units of glyceraldehyde phosphate dehydrogenase, and $0.1 \mathrm{~mL}$ of crude enzyme extract, with a total volume of $3.0 \mathrm{~mL}$. Prior to adding $\mathrm{RuBP}$, solution was placed at $30^{\circ} \mathrm{C}$ in water bath for $10 \mathrm{~min}$. After that, the solution was exposed to colorimetric determination using an spectrophotometer ( $U V$ 2401, Shimadzu Corporation, Japan) immediately after the substrate was added. $\mathrm{Ca}^{2+}$-ATPase and $\mathrm{Mg}^{2+}$-ATPase activities were measured according to Huang (1985). Assays were carried out at $30^{\circ} \mathrm{C}$ for $30 \mathrm{~min}$ in $0.5 \mathrm{~mL}$ reaction volume containing $1 \mathrm{mmol}\left(\right.$ Tris-ATP) $\mathrm{L}^{-1}, 1 \mathrm{mM}$ $\operatorname{mol}\left(\mathrm{MgSO}_{4}\right) \mathrm{L}^{-1}$ or $2 \mathrm{mmol}\left(\mathrm{CaSO}_{4}\right) \mathrm{L}^{-1}, 40 \mathrm{mmol}$ (TrisMES) $\mathrm{L}^{-1}$ (pH variable), $0.02 \%(\mathrm{w} / \mathrm{v})$ Triton $X-100$, with or without $25 \mathrm{mM} \mathrm{K}_{2} \mathrm{SO}_{4}$. The reaction was initiated by addition of the enzyme and terminated by adding $1 \mathrm{~mL}$ of color development solution, containing $0.75 \%(\mathrm{w} / \mathrm{v})$ $\left(\mathrm{NH}_{4}\right)_{6} \mathrm{Mo}_{7} \mathrm{O}_{24}, 0.375 \mathrm{M} \mathrm{H}_{2} \mathrm{SO}_{4}, 3 \%$ (w/v) $\mathrm{FeSO}_{4}$, and 0.75 (w/v) SDS. After $10 \mathrm{~min}, 0.5 \mathrm{~mL} \mathrm{7 \% (w/v)} \mathrm{sodium} \mathrm{citrate}$ was added to prevent further color development due to non-enzymatic hydrolysis of ATP. The activitites of nitrate reductase (NR) were determined with commercially available kits (COMIN, Suzhou, China).

Statistical analysis: Analysis of variance (ANOVA) was performed with SPSS version 11.5. Means were separated using Duncan's multiple range test at $P<0.05$. The figures were plotted using Sigma Plot version 10.0. The data are presented as mean \pm standard error (SE).

boll-setting stage under both $\mathrm{P}$ conditions. However, $C_{\mathrm{i}}$ increased under $\mathrm{P}^{-}$for $\mathrm{LP}$ and MP cultivars at various growth stages compared to others. Compared to $\mathrm{P}^{-}$, leaf gas-exchange parameters and $g_{\mathrm{m}}$ conductance were higher at different growth phases under $\mathrm{P}^{+}$.

Cotton plant growth characteristics: Cotton growth characteristics, i.e., LAI, CGR, NAR, and PP were significantly impacted by variable $\mathrm{P}$ environment at different reproductive stages. As the plants grew, LAI of different cultivars increased under both conditions. The LAI of all cultivars was the highest at the boll-setting stage under $\mathrm{P}^{+}$compared to $\mathrm{P}^{-}$(Fig. 1). Compared to other 
cultivars, HP cultivars had higher LAI during the bollsetting phase under $\mathrm{P}^{-}$conditions. However, the no significant differences were found between MP varieties and LP cultivars during the flowering stage. Furthermore, at the full flowering stage, the difference between HP cultivars and MP cultivars was not significant.

Data regarding CGR, NAR, and PP of different cultivars under the influence of variable $\mathrm{P}$ environments are presented (Fig. 2). HP cultivars performed better in terms of greater CGR under both conditions. CGR was significantly reduced for $\mathrm{P}^{-}$compared to $\mathrm{P}^{+}$for all cultivars. Nitrate reductase activity and photosynthetic capacity for high P-efficient cultivars were increased for $\mathrm{P}^{+}$treatment but reduced under $\mathrm{P}^{-}$conditions. The HP cultivars were efficient in terms of greater CGR, NAR, and $\mathrm{PP}$ under $\mathrm{P}^{-}$.

Table 1. Cotton leaf chlorophyll (Chl) content and leaf gas-exchange parameters as influenced by phosphorus and cultivars at various reproductive stages. $\mathrm{L}, \mathrm{M}$, and $\mathrm{H}$ indicate the average values of $\mathrm{L}_{1}-\mathrm{L}_{3}, \mathrm{M}_{1}-\mathrm{M}_{3}$, and $\mathrm{H}_{1}-\mathrm{H}_{3}$, respectively. Data represent the mean \pm standard error $(n=4)$. Means within a column followed by the same letters are not significantly different at $P<0.05$ according to Duncan's multiple range test.

\begin{tabular}{|c|c|c|c|c|c|c|c|}
\hline & Cultivar & $\begin{array}{l}\text { Squaring } \\
\mathrm{P}^{+}\end{array}$ & $\mathrm{P}^{-}$ & $\begin{array}{l}\text { Flowering } \\
\mathrm{P}^{+}\end{array}$ & $\mathrm{P}^{-}$ & $\begin{array}{l}\text { Boll setting } \\
\mathrm{P}^{+}\end{array}$ & $\mathrm{P}^{-}$ \\
\hline Chl & $\mathrm{L}$ & $5.48 \pm 0.14^{\mathrm{a}}$ & $5.07 \pm 0.34^{\mathrm{a}}$ & $6.24 \pm 0.21^{\mathrm{a}}$ & $5.24 \pm 0.28^{\mathrm{a}}$ & $5.15 \pm 0.12^{\mathrm{a}}$ & $4.21 \pm 0.37^{\mathrm{a}}$ \\
\hline \multirow[t]{2}{*}[\mathrm{mg}\mathrm{g}^{-1}(\mathrm{FM})]{} & $\mathrm{M}$ & $5.84 \pm 0.24^{\mathrm{a}}$ & $5.29 \pm 0.25^{\mathrm{a}}$ & $6.54 \pm 0.31^{\mathrm{a}}$ & $5.47 \pm 0.24^{\mathrm{a}}$ & $5.14 \pm 0.42^{\mathrm{a}}$ & $4.34 \pm 0.36^{\mathrm{a}}$ \\
\hline & $\mathrm{H}$ & $5.63 \pm 0.35^{\mathrm{a}}$ & $5.37 \pm 0.41^{\mathrm{a}}$ & $6.87 \pm 0.42^{\mathrm{a}}$ & $5.64 \pm 0.23^{\mathrm{a}}$ & $4.84 \pm 0.23^{\mathrm{a}}$ & $4.52 \pm 0.35^{\mathrm{a}}$ \\
\hline$g_{\mathrm{s}}$ & $\mathrm{L}$ & $0.65 \pm 0.02^{\mathrm{ab}}$ & $0.42 \pm 0.02 \mathrm{c}$ & $0.88 \pm 0.04^{\mathrm{a}}$ & $0.59 \pm 0.03^{c}$ & $0.53 \pm 0.04^{\mathrm{b}}$ & $0.30 \pm 0.01^{\mathrm{c}}$ \\
\hline \multirow[t]{2}{*}[\mathrm{mol}(\mathrm{H}_{2}\mathrm{O})\mathrm{m}^{-2}\mathrm{s}^{-1}]{} & $\mathrm{M}$ & $0.62 \pm 0.03^{\mathrm{b}}$ & $0.51 \pm 0.03 b$ & $0.93 \pm 0.04^{\mathrm{a}}$ & $0.63 \pm 0.03^{b}$ & $0.51 \pm 0.03^{b}$ & $0.34 \pm 0.01^{\mathrm{b}}$ \\
\hline & $\mathrm{H}$ & $0.68 \pm 0.04^{\mathrm{a}}$ & $0.60 \pm 0.02 \mathrm{a}$ & $0.90 \pm 0.03^{\mathrm{a}}$ & $0.73 \pm 0.02^{\mathrm{a}}$ & $0.57 \pm 0.04^{\mathrm{a}}$ & $0.41 \pm 0.02^{\mathrm{a}}$ \\
\hline$g_{\mathrm{m}}$ & $\mathrm{L}$ & $0.52 \pm 0.03^{b}$ & $0.34 \pm 0.04^{\mathrm{c}}$ & $0.75 \pm 0.04^{\mathrm{a}}$ & $0.44 \pm 0.02^{\mathrm{c}}$ & $0.46 \pm 0.03^{\mathrm{b}}$ & $0.20 \pm 0.01^{\mathrm{c}}$ \\
\hline \multirow[t]{2}{*}[\mathrm{mol}(\mathrm{H}_{2}\mathrm{O})\mathrm{m}^{-2}\mathrm{s}^{-1}]{} & $\mathrm{M}$ & $0.53 \pm 0.02^{b}$ & $0.40 \pm 0.02^{\mathrm{b}}$ & $0.74 \pm 0.05^{\mathrm{a}}$ & $0.52 \pm 0.02^{\mathrm{b}}$ & $0.48 \pm 0.03^{\mathrm{b}}$ & $0.26 \pm 0.01^{\mathrm{b}}$ \\
\hline & $\mathrm{H}$ & $0.58 \pm 0.04^{\mathrm{a}}$ & $0.45 \pm 0.03^{\mathrm{a}}$ & $0.77 \pm 0.04^{\mathrm{a}}$ & $0.57 \pm 0.04^{\mathrm{a}}$ & $0.52 \pm 0.04^{\mathrm{a}}$ & $0.32 \pm 0.02^{\mathrm{a}}$ \\
\hline$P_{\mathrm{N}}$ & $\mathrm{L}$ & $26.3 \pm 2.2^{\mathrm{b}}$ & $22.2 \pm 2.0^{\mathrm{b}}$ & $35.4 \pm 1.6^{\mathrm{b}}$ & $27.6 \pm 2.0^{\mathrm{c}}$ & $22.0 \pm 1.5^{\mathrm{b}}$ & $15.3 \pm 0.8^{\mathrm{c}}$ \\
\hline \multirow[t]{2}{*}[\mu\mathrm{mol}(\mathrm{CO}_{2})\mathrm{m}^{-2}\mathrm{s}^{-1}]{} & $\mathrm{M}$ & $27.5 \pm 2.8^{\mathrm{ab}}$ & $23.9 \pm 2.4^{\mathrm{ab}}$ & $36.8 \pm 2.1^{\mathrm{ab}}$ & $30.0 \pm 1.1^{\mathrm{b}}$ & $23.9 \pm 1.4^{\mathrm{ab}}$ & $19.6 \pm 0.8^{\mathrm{b}}$ \\
\hline & $\mathrm{H}$ & $29.4 \pm 2.9^{\mathrm{a}}$ & $25.0 \pm 1.2^{\mathrm{a}}$ & $38.4 \pm 2.8^{\mathrm{a}}$ & $33.0 \pm 2.2^{\mathrm{a}}$ & $24.3 \pm 2.0^{\mathrm{a}}$ & $23.8 \pm 1.2^{\mathrm{a}}$ \\
\hline$C_{\mathrm{i}}$ & $\mathrm{L}$ & $276 \pm 18^{a}$ & $301 \pm 17^{\mathrm{a}}$ & $207 \pm 15^{\mathrm{a}}$ & $255 \pm 14^{\mathrm{a}}$ & $307 \pm 19^{a}$ & $324 \pm 14^{\mathrm{a}}$ \\
\hline \multirow[t]{2}{*}[\mu\mathrm{mol}(\mathrm{CO}_{2})\mathrm{mol}^{-1}]{} & M & $265 \pm 13^{\mathrm{ab}}$ & $284 \pm 14^{\mathrm{b}}$ & $201 \pm 14^{\mathrm{ab}}$ & $220 \pm 12^{b}$ & $294 \pm 15^{\mathrm{a}}$ & $301 \pm 12^{\mathrm{b}}$ \\
\hline & $\mathrm{H}$ & $244 \pm 16^{\mathrm{b}}$ & $259 \pm 11^{\mathrm{c}}$ & $162 \pm 17^{\mathrm{b}}$ & $189 \pm 14^{\mathrm{c}}$ & $261 \pm 12^{\mathrm{b}}$ & $272 \pm 11^{\mathrm{c}}$ \\
\hline
\end{tabular}

$\mathrm{Ca}^{2+}$-ATPase and $\mathrm{Mg}^{2+}$-ATPase activities: Data regarding $\mathrm{Ca}^{2+}$-ATPase and $\mathrm{Mg}^{2+}$-ATPase activities under the influence of variable $\mathrm{P}$ environment are shown in Fig. 3. $\mathrm{Mg}^{2+}$-ATPase and $\mathrm{Ca}^{2+}$-ATPase activity were higher during the full squaring stage, but decreased in the flowering and boll-setting stages at $\mathrm{P}^{+}$and $\mathrm{P}^{-}$. Among the cultivars, HP cultivars were the most efficient in terms of higher $\mathrm{Mg}^{2+}$-ATPase and $\mathrm{Ca}^{2+}$-ATPase activity under both $P$ conditions during the full budding stage followed by full flowering and boll-setting stage. However, the $\mathrm{Mg}^{2+}$ ATPase and $\mathrm{Ca}^{2+}$-ATPase activities significantly declined under $\mathrm{P}^{-}$during all growth stages.

Soluble protein content and Rubisco activity: Both $\mathrm{P}^{+}$ and $\mathrm{P}^{-}$significantly influenced leaf soluble protein content and Rubisco activity at various reproductive phases (Fig. 4). Compared to LP and MP, HP cultivars showed the highest soluble protein content at the full flowering stage under both conditions. A substantial reduction in soluble protein content was observed during the squaring stage.

\section{Discussion}

Phosphorus is multifunctional plant macronutrient used to maximize plant growth and yield. Therefore, reductions in
Rubisco activity was maximum during the full flowering stage for HP cultivars but it was reduced at the boll-setting stage under both $\mathrm{P}^{+}$and $\mathrm{P}^{-}$conditions. Compared to $\mathrm{P}^{+}$ conditions, a substantial reduction in protein contents and Rubisco activity was noted under $\mathrm{P}^{-}$.

Cotton yield, phosphorus uptake and utilization efficiency: Cotton yield, $\mathrm{P}$ uptake, and utilization efficiency of cotton cultivars under $\mathrm{P}^{+}$and $\mathrm{P}^{-}$are presented in Fig. 5. HP cultivars $\left(\mathrm{H}_{1}-\mathrm{H}_{3}\right)$ produced a higher seed yield than other cultivars under $\mathrm{P}^{+}$conditions. Similar trend was also observed under $\mathrm{P}^{-}$conditions. A substantial reduction in cotton yield was noted under $\mathrm{P}^{-}$conditions compared to $\mathrm{P}^{+}$(Fig. 5). Significant reductions in $\mathrm{P}$ accumulations were noticed for cotton cultivars under $\mathrm{P}^{-}$conditions. HP cultivars resulted in higher $\mathrm{P}$ accumulation compared to MP and LP cultivars under $\mathrm{P}^{+}$. MP $\left(\mathrm{M}_{1}-\mathrm{M}_{3}\right)$ cultivars had high P-use efficiency compared to other cultivars. However, the P-use efficiency was higher under $\mathrm{P}^{-}$ conditions relative to $\mathrm{P}^{+}$for MP cultivars.

the supply of $\mathrm{P}$ fertilizers could severely diminish crop yields (Yan et al. 1997, 2000). It is the major component 
of nucleic acids, phosphatides (components of cell membrane), ATP, and photosynthetic parameters of cotton crops (Schachtman et al. 1998, Raines 2011, Luo et al. 2016). One solution for mitigating the threat of this diminishing resource is to develop sustainable technologies to improve P-use efficiency for plant uptake. Crop management practices, i.e., selection of cultivars and $\mathrm{P}$ fertilization are the most important factors for maximizing cotton yield.

In this study, leaf $\mathrm{Chl}$ content and gas-exchange parameters were impacted by $\mathrm{P}$ supply and different cultivars. We found significant correlations between $P_{\mathrm{N}}$ and $g_{\mathrm{s}}$ at the growth stages as well as between $P_{\mathrm{N}}$ and the nonstomatal conductance of cultivars with different $\mathrm{P}$ efficiencies. These data indicate that the $P_{\mathrm{N}}$ improvement of HP cultivars without $\mathrm{P}$ application can be ascribed to the improvement of transport capacity for $\mathrm{CO}_{2}$ toward photosynthetic carboxylation sites. The $\mathrm{CO}_{2}$ in the liquid phase was separated by the carbonic anhydrase

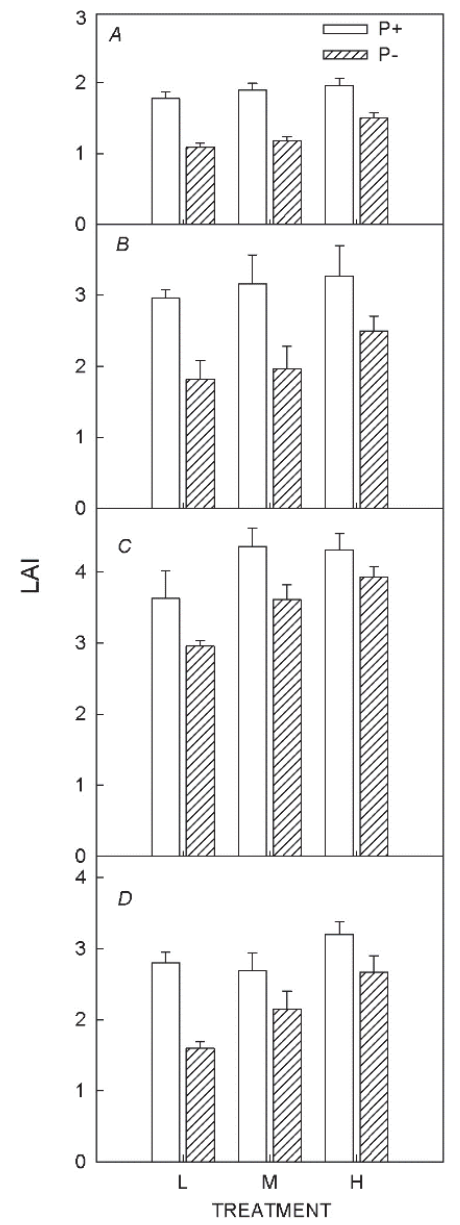

Fig. 1. Values of LAI at the full budding stage $(A)$, full flowering stage $(B)$, full bolling stage $(C)$, and later full bolling stage $(D)$ in cultivars with different $P$ efficiencies. $\mathrm{P}^{+}\left(70 \mathrm{~kg} \mathrm{ha}{ }^{-1}\right)$ $\mathrm{P}^{-}\left(0 \mathrm{~kg} \mathrm{ha}^{-1}\right), \mathrm{L}, \mathrm{M}$, and $\mathrm{H}$ represent low-efficient, medium-, and high-P-efficient cultivars, respectively. Data represent the mean \pm standard error $(n=4)$. of $\mathrm{HCO}_{3}{ }^{-}$to enhance the transportation of $\mathrm{CO}_{2}$ in cotton leaf physiognomy by transporting $\mathrm{CO}_{2}$ at an ionic state into liquid phase (Raines 2011). This phenomenon might be an important internal reason for the increase of the $g_{\mathrm{m}}$ in HP cultivars under $\mathrm{P}^{-}$condition in order to relieve the stomatal limitation of photosynthesis. The increment in leaf photosynthetic capacity might be associated with greater $\mathrm{P}$ uptake and utilization efficiency with improved leaf photosynthetic rate. This indicates that sufficient $P$ has the potential to improve cotton leaf photosynthetic capacity. In the present study, intercellular $\mathrm{CO}_{2}$ concentration of LP cultivars increased under both $\mathrm{P}$ rates. The $\mathrm{CO}_{2}$ concentration is essential to maximize photosynthesis but depends on crop species and environmental conditions $(\mathrm{Ku}$ et al. 1977). Stomatal conductance may respond to changes in photosynthetic rate to maintain $C_{\mathrm{i}}$ near saturation. Physiologists generally believe that stomata function to prevent desiccation while still allowing the passage of $\mathrm{CO}_{2}$. Stomata impose a large limitation on the rate of $\mathrm{CO}_{2}$ assimilation as well as limit $\mathrm{CO}_{2}$ assimilation of $\mathrm{C}_{4}$ plants more compared to $\mathrm{C}_{3}$ plants. The stomatal limitation of photosynthesis is often thought of as the contribution of stomatal resistance to some total "resistance" to $\mathrm{CO}_{2}$ uptake. Stomatal limitation decreased despite a decrease in $C_{\mathrm{i}}$ (Farquhar et al. 1982). Increment in leaf conductance of $\mathrm{CO}_{2}$ did not contribute to $P_{\mathrm{N}}$ although external $\mathrm{CO}_{2}$ concentration did not increase $P_{\mathrm{N}}$ even though $C_{\mathrm{i}}$ increased (Perry et al. 1983).

Cotton growth and leaf enzymatic activity was significantly influenced by both factors. HP cotton cultivars exhibited relatively higher NAR under $\mathrm{P}^{-}$conditions. This data indicates that these cultivars possess high leaf photosynthetic efficiency. Furthermore, the high PP of HP cultivars was closely related to the high LAI at full flowering and boll-setting stages. In this research, High-P efficiency varieties resulted in higher $P_{\mathrm{N}}, \mathrm{NAR}$, and PP during yield formation under $\mathrm{P}^{-}$conditions. This further led to high CGR and more seed cotton yield during boll opening stage. Leaf enzymatic activity, i.e., $\mathrm{Ca}^{2+}$-ATPase and $\mathrm{Mg}^{2+}$-ATPase activities increased under rich supply of P. This might be due to higher photosystem PSII activity of HP, $\mathrm{P}$ acquisition and utilization efficiency. The reductions in the supply of $P$ fertilizers severely diminish cotton growth (Baas et al. 2016).

Soluble protein content and Rubisco activity significantly increased under $\mathrm{P}^{+}$. Rubisco influences the darkreaction efficiency of photosynthesis (Xiao et al. 1998). Hence, high soluble protein content is the physiological foundation for highly efficient metabolism of the plant (Friedrich and Huffaker 1980). Rubisco activity directly influences photosynthetic dark reaction efficiency. Increasing the supply of inorganic $\mathrm{P}$ in the chloroplasts can improve the carboxylation efficiency of Rubisco, the key enzyme of photosynthesis (Mächler 1984). Deficient P supply decreases leaf $\mathrm{Chl}$ and soluble protein content (Pan et al. 2003). Pan et al. (2003) found that the soluble protein, RuBP content, and activity in rice leaves 
decreased under low $\mathrm{P}$ condition compared to adequate $\mathrm{P}$ supply. In the present study, the Rubisco activity at the yield-formation stage increased as the $\mathrm{P}$ efficiency of cotton cultivars increased. Rubisco activity and $P_{\mathrm{N}}$ during the test period had a significant positive correlation.

Cotton yield, P-uptake and use efficiency was higher under $\mathrm{P}^{+}$compared to $\mathrm{P}^{-}$conditions. The increment in the cotton yield was mainly associated with higher $\mathrm{P}$ uptake which further promoted leaf photosynthetic capacity. Soils with a large capacity to bind $\mathrm{P}$ are especially because of $\mathrm{P}$ delivery to plants requires more inputs relative to the $\mathrm{P}$ outputs in harvested crops (MacDonald et al. 2011), resulting in extremely low agricultural P-use efficiency. Soil bacteria can strongly influence the amount of soil $\mathrm{P}$ which is plant-available by solubilizing the mineralassociated P (Osorio and Habte 2014), and increasing plant P uptake by stimulating plant root growth (Bal et al. 2013). This is achieved by releasing metabolites including organic acids and high-affinity iron chelating (siderophores which solubilize mineral-bound P Shropshire and Bordenstein 2016) and by exuding plant hormones such as auxin (Spaepen 2015).

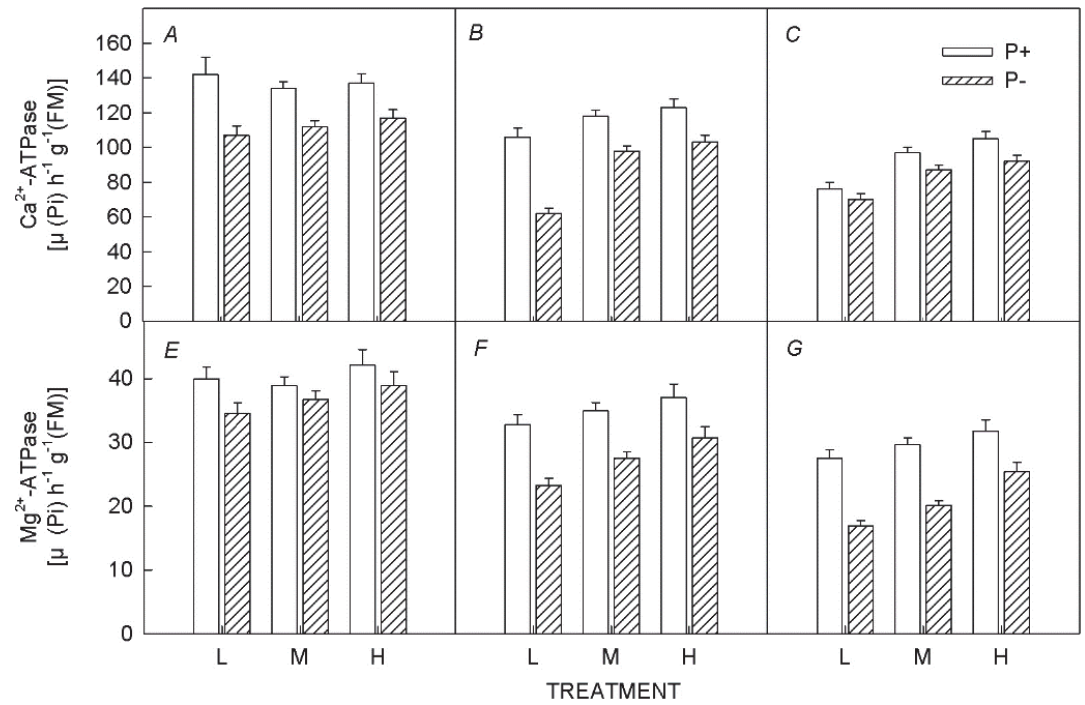

Fig. 2. Values of population growth parameters (CGR, $A$; NAR, $B$; PP, $C)$ during the full squaring and boll setting stages in cultivars with different $\mathrm{P}$ efficiencies. $\mathrm{P}^{+}\left(70 \mathrm{~kg} \mathrm{ha}^{-1}\right) \mathrm{P}^{-}\left(0 \mathrm{~kg} \mathrm{ha}^{-1}\right), \mathrm{L}, \mathrm{M}, \mathrm{H}$ represent low-efficient, medium-, and high-P-efficient cultivars, respectively. Data represent the mean \pm standard error $(n=4)$.

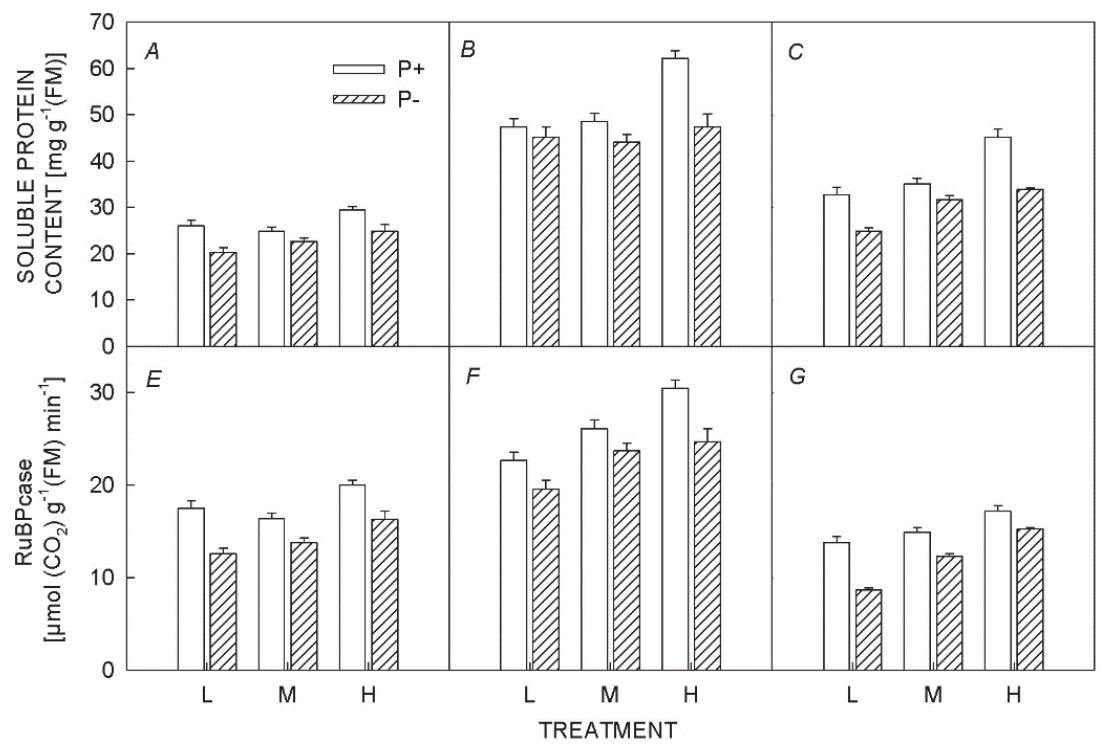

Fig. 3. Cotton cultivars leaf $\mathrm{Ca}^{2+}$-ATPase and $\mathrm{Mg}^{2+}$-ATPase activities during full squaring $(A, E)$, full flowering $(B, F)$, and boll setting stage $(C, G)$ as influenced by $\mathrm{P}^{+}$and $\mathrm{P}^{-} . \mathrm{P}^{+}\left(70 \mathrm{~kg} \mathrm{ha}^{-1}\right) \mathrm{P}^{-}\left(0 \mathrm{~kg} \mathrm{ha}^{-1}\right), \mathrm{L}, \mathrm{M}, \mathrm{H}$ represent low-efficient, medium-, and high-P-efficient cultivars, respectively. Data represent the mean \pm standard error $(n=4)$. 


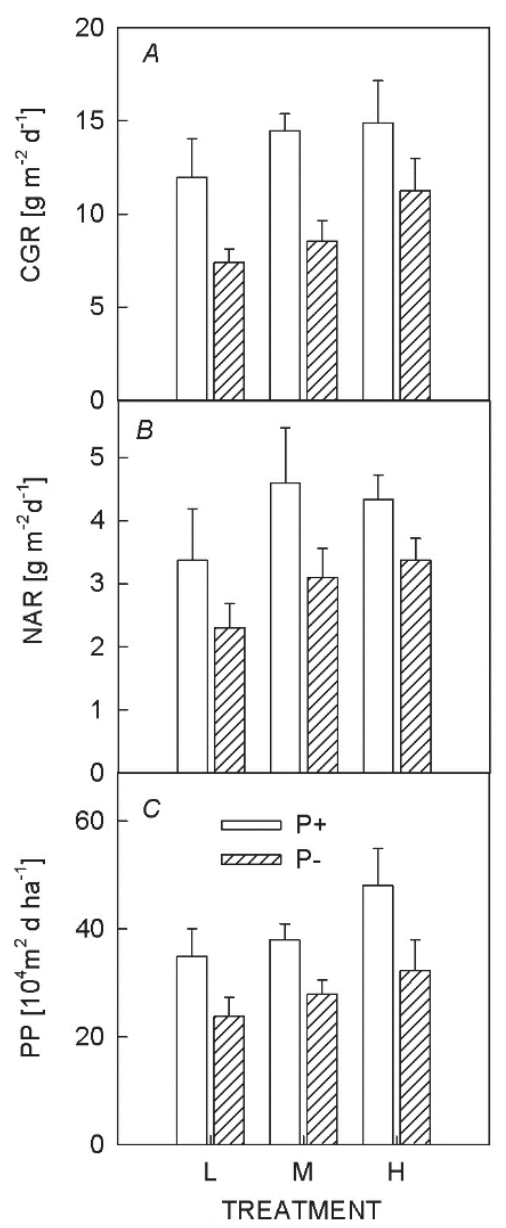

Fig. 4. Soluble protein contents and Rubisco activities of cotton leaves at full squaring $(A, E)$, full flowering $(B, F)$, and full boll setting stage $(C, G)$ as influenced by variable $\mathrm{P}$ environments. $\mathrm{P}^{+}\left(70 \mathrm{~kg} \mathrm{ha}^{-1}\right) \mathrm{P}^{-}\left(0 \mathrm{~kg} \mathrm{ha}^{-1}\right), \mathrm{L}$, $\mathrm{M}, \mathrm{H}$ represent low-efficient, medium-, and high-P-efficient cultivars, respectively. Data represent the mean \pm standard error $(n=4)$.

Conclusion: In this study, $\mathrm{P}^{+}$and $\mathrm{P}^{-}$significantly influenced cotton growth, yield, and physiology. Under $\mathrm{P}^{+}$ supply increased crop growth, soluble protein content, and leaf gas-exchange parameters might be associated with higher $\mathrm{P}$ acquisition and utilization efficiency. $\mathrm{P}^{-}$ significantly hampered cotton growth and physiological activity. The increment in cotton yield under $\mathrm{P}^{+}$with high-

\section{References}

Baas P., Bell C., Mancini L.M. et al.: Phosphorus mobilizing consortium Mammoth PTM enhances plant growth. - Peer. J. 4: 2121, 2016.

Bal H.B., Nayak L., Das S., Adhya T.K.: Isolation of ACC deaminase producing PGPR from rice rhizosphere and evaluating their plant growth promoting activity under salt
$P$ cultivars was associated with greater enzymatic activity and more $\mathrm{P}$ uptake during the reproductive phase, resulting in higher leaf photosynthetic capacity. These data can be used to develop a crop management strategy for improving cotton growth and yield in arid region of Xinjiang China and globally.

stress. - Plant Soil 366: 93-105, 2013.

Baligar V.C., Barber S.A.: Genotypic differences of corn for ion uptake. - Agron. J. 71: 870-873, 1979.

Bradford M.M.: A rapid and sensitive method for the quantitation of microgram quantities of protein utilizing the principle of protein-dye binding. - Anal. Biochem. 72: 248-254, 1976. 
Bremer J.M., Mulvaney C.S.: Total nitrogen. - In: Page A.L., Miller R.H., Keeny D.R. (ed.): Methods of Soil Analysis, part 2. Chemical and Microbiological Properties. Pp. 595-624. American Society of Agronomy Inc., Soil Science Society of America Inc., Madison, Wisconsin 1980.

Dong Y.H., Shi J.P., Li G.M., Shang Z.Q.: Effect of spermine and sperimidine on photosynthetic carboxylase activity of detached maize leaves in light. - Plant Physiol. Co. 32: 268270, 1996. [In Chinese]

Farquhar G.D., Sharkey T.D.: Stomatal conductance and photosynthesis. - Annu. Rev. Plant. Physio. 33: 317-345, 1982.

Friedrich J.W., Huffaker R.C.: Photosynthesis, leaf resistance and ribulose-1,5-bisphosphate carboxylase degradation in senecing barely leaves. - Plant Physiol. 65: 1103-1107, 1980.

Girma K, Teal R.K., Freeman K.W. et al.: Cotton lint yield and quality as affected by applications of $\mathrm{N}, \mathrm{P}$, and $\mathrm{K}$ fertilizers. J. Cotton Sci. 11: 12-19, 2007.

He P., Osaki M., Takebe M., Shinano T.: Changes of photosynthetic characteristics in relation to leaf senescence in two maize hybrids with different senescent appearance. Photosynthetica 40: 547-552, 2002.

Huang Z.H.: Measurement of ATPase in Chloroplast. Brochure of Experiment in Plant Physiology. Pp. 111-115. Shanghai Sci. Teconol. Press, 1985.

Jayakumar M., Surendran U.: Intercropping and balanced nutrient management for sustainable cotton production. - J. Plant Nutri. 40: 632-644, 2017.

Jensen H., Schjoerring J., Soussana J.F.: The influence of phosphorus deficiency on photosynthesis in sunflower and soybean plants. - Ann. Bot.-London 90: 745-753, 2002.

$\mathrm{Ku}$ S., Edwards G.: Oxygen inhibition of photosynthesis. II. Kinetic characteristics as affected by temperature. - Plant Physiol. 59: 991-999,1977.

Lauer M.J., Pallardy S.G., Blevins D.G.: Whole leaf carbon exchange characteristic of phosphate deficient soybean. - Plant Physiol. 91: 848-854, 1989.

Lauer M.J., Pallardy S.G., Blevins D.G., Randall D.D.: Whole leaf carbon exchange characteristics of phosphate deficient soybeans (Glycine max L.). - Plant Physiol. 91: 848-854, 1989.

Lefebvre D.D., Duff S.M.G., Fife C. et al.: Response to phosphate deprivation in Bassica nigra suspension cells. Enhancement of intracellular, cell surface and secreted phosphatase activities compared to increases in pi-absorption rate. - Plant Physiol. 93: 504-511, 1990.

Li W.H., Sheng J.D., Chen B.L., Fu D.L., Li J.: Studies on screening cotton varieties by high efficient use of phosphorous nutrient. - J. Xinjiang Agr. Univ. 33: 109-115, 2010. [In Chinese]

Liu J.Z., Li J.Y.: Utilization of plant potentialities to enhace the bio-efficiency of phosphorus in soil. - Eco-Agri. Res. 2: 16-23, 1994. [In Chinese]

Luo H.H., Zhang Y.L., Zhang W.F.: Effects of water stress and rewatering on photosynthesis, root activity, and yield of cotton with drip irrigation under mulch. - Photosynthetica 54: 65-73, 2016.

Luo J., Hou Y.Y., Cheng J.H. et al.: Root morphological characteristics of cotton genotypes with different phosphorus efficiency under phosphorus stress. - Sci. Agri. Sin. 49: 22802289, 2016. [In Chinese]

MacDonald G.K., Bennett E.M., Potter P.A., Ramankutty N.: Agronomic phosphorus imbalances across the world's croplands. - P. Natl. Acad. Sci. USA 108: 3086-3091, 2011.
Mächler F., Schnyder H., Nösberger J.: Influence of inorganic phosphate on photosynthesis of wheat chloroplast. - J. Exp. Bot. 35: 481-487, 1984.

Muchhal U.S., Raghothama K.G.: Transcriptional regulation of plant phosphate transporters. - P. Natl. Acad. Sci. USA 96: 5868-5872, 1999.

Osorio N.W., Habte M.: Soil phosphate desorption induced by a phosphate solubilizing fungus. - Commun. Soil Sci. Plan. 45:451-460, 2014

Pan X.H., Liu S.Y., Li F., Li M.Y.: Effects of phosphate stress on photosynthesis of rice (Oriza sativa) seedlings. - Acta Agron. Sin. 29: 770-774, 2003. [In Chinese]

Perry S.W., Krieg D.R., Hutwacher R.B.: Photosynthetic rate control in cotton. - Plant Physiol. 73: 658-666, 1983.

Raines C.A.: Increasing photosynthetica carbon assimilation in $\mathrm{C}_{3}$ plant to improve crop yield: Current and futures strategies. - Plant Physiol. 155: 36-42, 2011.

Randriamanantsoa L., Morel C., Rabeharisoa L. et al.: Can the isotopic exchange kinetic method be used in soils with a very low water extractable phosphate content and a high sorbing capacity for phosphate ions? - Geoderma 200: 120-129, 2013.

Rao I.M, Terry N.: Leaf phosphate status, photosynthesis, and carbon partitioning in sugar beet. I. Changes in growth, gas exchange, and Calvin cycle enzymes. - Plant Physiol. 90: 814$819,1989$.

Schachtman D.P., Reid R.J., Ayling S.M.: Phosphorus uptake by plants: from soil to cell. - Plant Physiol. 116: 447-453, 1998.

Sharpley A.N., Bergström L., Aronsson H. et al.: Future agriculture with minimized phosphorus losses to water: Resesearh needs and directions. - Ambio 44: 163-179, 2015.

Shropshire J.D., Bordenstein S.R.: Speciation by symbiosis: the microbiome and behavior. - MBio 7: e01785-15, 2016.

Spaepen S.: Plant hormones produced by microbes. - In: Lugtenberg B.: Principles of Plant-Microbe Interactions. Pp. 247-256. Springer, Berlin - Heidelberg 2015.

Surendran U., Murugappan V.: Pragmatic approaches to manage soil fertility in sustainable agriculture. - J. Agron. 9: 57-69, 2010.

Suriyagoda L., De Costa W.A.J.M., Lambers H.: Growth and phosphorus nutrition of rice when inorganic fertiliser application is partly replaced by straw under varying moisture availability in sandy and clay soils. - Plant Soil 384: 53-68, 2014.

Wang X., Tang C., Guppy C.N., Sale P.W.G.: Phosphorus acquisition characteristics of cotton (Gossypium hirsutum L.), wheat (Triticum aestivum L.) and white lupin (Lupiuns albus L.) under P deficient conditions. - Plant Soil 312: 117-128, 2008.

Wang Y., Li X.L.: Progress in adaptive mechanisms of different genotypic plants to low phosphorus stress. - Eco-Agr. Res. 8: 34-36, 2000. [In Chinese]

Xiao K., Gu J.T., Zou D.H.: Studies on $\mathrm{CO}_{2}$ conductance during flag leaf aging of hybrids wheats and their parents. - Acta Agron. Sin. 24: 503-506, 1998. [In Chinese]

Xiao K., Zhang R.X., Zou D.H., Qian W.P.: Studies on rubisco characteristics during flag leaf aging in hybrid wheat and its parents. - Acta Bot. Sin. 40: 343-348, 1998. [In Chinese]

Yan X.L., Liao H., Ge Z.Y., Luo X.W.: Root architectural characteristics and phosphorus acquisition efficiency in plants. - Chin. Bull. Bot. 17: 511-519, 2000. [In Chinese]

Yan X.L., Zhang F.S.: Genetics of Plant Nutrition. Pp. 24-30. Chinese Agriculture Press, Beijing 1997. 